\title{
Structure of non-reimbursed and reimbursed therapeutic procedures provided at a general dental care office
}

\author{
Sylwia ZgardZinska ${ }^{1}$, Jolanta Szymanska ${ }^{2 \star}$
}

${ }^{1}$ Family Dentistry Office, Rzeszow, Poland

${ }^{2}$ Chair and Department of Paedodontics, Medical University of Lublin, Poland

\section{ARTICLE INFO \\ Received 3 September 2014 \\ Accepted 15 October 2014}

\section{Keywords:}

general dentistry,

dental treatment,

funding source.

\begin{abstract}
Dental care in Poland is based both on the public system (reimbursement by the National Health Fund) and on the private funding (non-reimbursed). The aim of the paper was an analysis of the structure of non-reimbursed and reimbursed therapeutic procedures provided at a general dental care office. The study material was medical documentation of 669 patients treated for 3 months (the third quarter of 2013) at a general dental care office. The structure of therapeutic procedures, with the exception of orthodontic and prosthetic treatment, was analyzed, taking into account the patients' gender, age, place of residence, the kind of procedure, and the payment type they made. The procedures reimbursed by the National Health Fund constituted $60.1 \%$ of all the procedures provided to patients at a dental office. Both among the procedures reimbursed by the National Health Fund and non-reimbursed procedures, the therapeutic procedures prevailed significantly over the prophylactic ones; in all age groups conservative treatment was predominant. An increase in the number of extractions in patients over 40 years of age, in comparison to younger patients, was found. The number of the dental procedures reimbursed by the National Health Fund, compared to the number of the non-reimbursed ones, increased with the patients' age.
\end{abstract}

\section{INTRODUCTION}

The principles of market economy operative in dental care compel service providers to perceive patients as service recipients. A continually updated analysis of the market of dental prophylactic-therapeutic services is necessary so that service providers could adapt to patients' needs, expectations and preferences, effectively compete for patients and consolidate their position in the market [6,9].

\section{AIM}

The aim of the paper was an analysis of the structure of non-reimbursed and reimbursed therapeutic procedures provided at a dental office localized in a large city in southeastern Poland.

\section{MATERIAL AND METHODS}

The study material was medical documentation of the patients treated for 3 months (the third quarter of 2013)

Corresponding author

e-mail: szymanska.lublin@gmail.com at a primary dental care office. The structure of treatment procedures, with the exception of orthodontic and prosthetic ones, was analyzed, taking into account the patients' gender, age, place of residence, the kind of procedure, and the kind of payment made by patients. The results were analyzed statistically. The values of the analyzed parameters, measured on a nominal scale, were characterized by frequency and percentage, while the correlation between the analyzed characteristics was assessed with $\chi^{2}$ independence test. The inference error of $5 \%$, and the related significance level of $\mathrm{p}<0.05$, indicating the occurrence of statistically significant differences, were assumed. The analyzed database and statistical analyses were made with Statistica 10.0 (StatSoft, Poland) software.

\section{RESULTS}

The group of 669 dentally treated patients comprised 348 men (52\%) and 321 women (48\%). The patients were divided into 3 age groups: developmental-age patients below 17 years of age, and 2 groups of adults - from 18-40 years and over 40 years. The group of patients aged 18-40 
was the largest (317 persons), which accounted for $47.4 \%$ of the total group. The group of patients over 40 was less numerous - $238(35.6 \%)$, and the group of patients younger than 17 years of age was the smallest - $114(17 \%)$. The great majority of the patients - $611(91.3 \%)$ were inhabitants of the city where the dental office was located, while 58 patients $(8.7 \%)$ came from the neighbouring towns and villages.

Conservative treatment was provided most frequently - in $53.7 \%$ of the total number of patients, extractions and endodontic treatment were less frequent - in 16\% and $13.9 \%$, respectively, which constituted $83.6 \%$ of all the procedures. Prophylactic procedures (sealing, varnishing, scaling) constituted $13.8 \%$, while other activities (ozonisation, sandblasting and dental whitening) accounted for $2.6 \%$ of all the procedures. Figure 1 shows the distribution of the performed procedures.

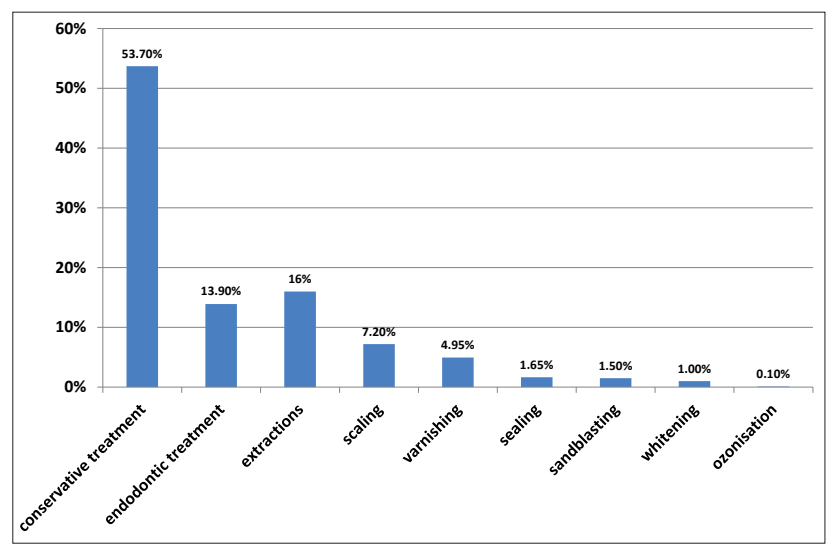

Figure 1. Types of procedures performed in patients

Services reimbursed by the National Health Fund were provided to 412 patients $(61.6 \%)$, while non-reimbursed - to 257 patients $(38.4 \%)$, and the difference was statistically significant. In the group of patients treated under a contract with the National Health Fund, therapeutic procedures constituted $91.99 \%$, while prophylactic ones $-8.01 \%$. Among the nonreimbursed patients, treatment procedures were $94.94 \%$, and the prophylactic ones $-5.06 \%$ of all performed procedures. In both cases, the differences were statistically significant.

Among the procedures reimbursed by the National Health Fund, $49.76 \%$ were conservative procedures, $25 \%$ - extractions, $9.71 \%$ - scaling, $7.28 \%$ - endodontic treatment, $6.07 \%$ - varnishing and $1.94 \%$ - sealing. In the non-reimbursed group, $59.92 \%$ were conservative procedures, $24.51 \%$ - endodontic treatment, 3.5\% - sandblasting, 2.72\% - varnishing and whitening, $2.33 \%$ - scaling, $1.56 \%$ - extractions, $1.17 \%$ - sealing, $0.78 \%$ - scaling and varnishing, $0.39 \%$ - scaling and sealing, and $0.39 \%$ - ozonisation. Figure 2 shows the distribution of procedures according to the payment type.

The analysis of procedures performed in patients of different age groups showed that conservative treatment was most frequent in the group of patients younger than 17 years of age $-53.51 \%$, less frequent were: varnishing, extractions and sealing - respectively $18.42 \%, 14.04 \%$ and $9.65 \%$ of all procedures in this age group. In the group of adults aged 18-40, conservative treatment constituted $59.62 \%$ of the procedures, endodontic treatment $-17.35 \%$, and extractions $-5.05 \%$. In patients over 40 years of age, the frequencies

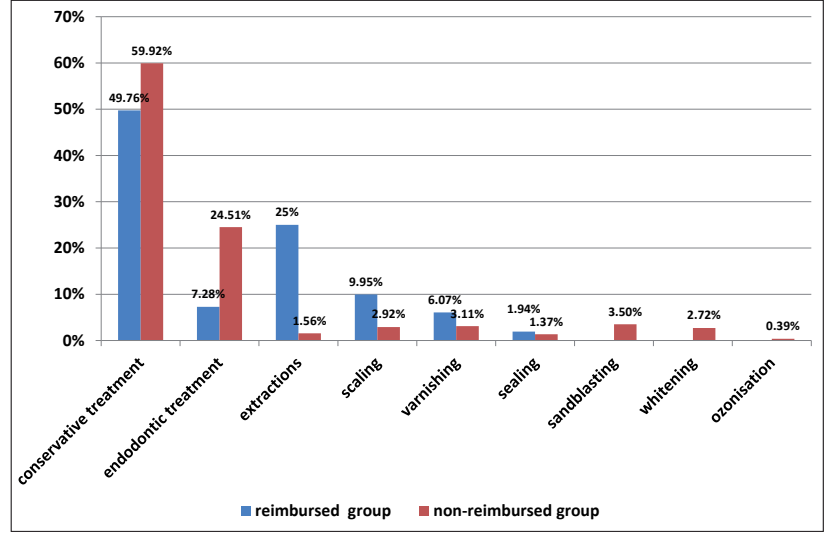

Figure 2. Types of reimbursed and non-reimbursed procedures performed in patients

of conservative treatment, extractions and endodontic treatment were, respectively, 45.8\%, 31.51\%, and 14.29\% of all the procedures in this age group. The analysis showed an increase in the number of conservative and endodontic procedures with age (age groups: below 17 and 18-40) and a decrease in these procedures, parallel to a large increase in the number of extractions, in the group of patients over 40 (Fig. 3).

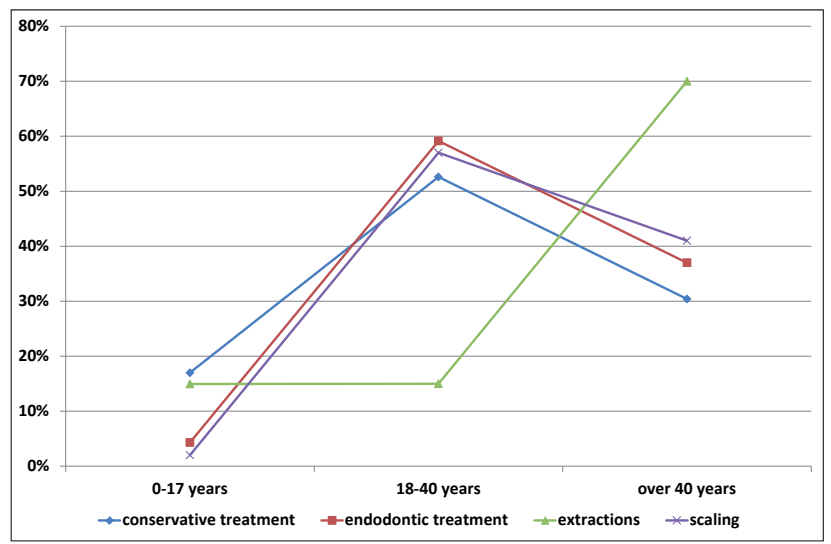

Figure 3. Type of procedures in different age groups

The analysis of the frequency of non-reimbursed procedures in comparison to those reimbursed by the National Health Fund in different age groups showed that in the group of patients below 17 years of age, $64.91 \%$ of the procedures were reimbursed, which constituted $17.96 \%$ of all reimbursed procedures in all age groups. In the age group 18-40 years, the reimbursed procedures were performed in $50.47 \%$ of patients, which was $38.83 \%$ of all reimbursed procedures, while in patients over 40 , those proportions were $74.49 \%$ and $43.2 \%$, respectively (Fig. 4 ).

The study of the correlation between the gender and the type of service showed no statistically significant differences, while women slightly more often had their treatment reimbursed by the National Health Fund than men did. The analysis of the dependence of the place of residence and age, however, showed a tendency to a statistically significant difference, while the study of the remaining variables showed no statistically significant differences.

A detailed report of the statistical analyses, in the form of tables and figures, can be obtained from the authors. 


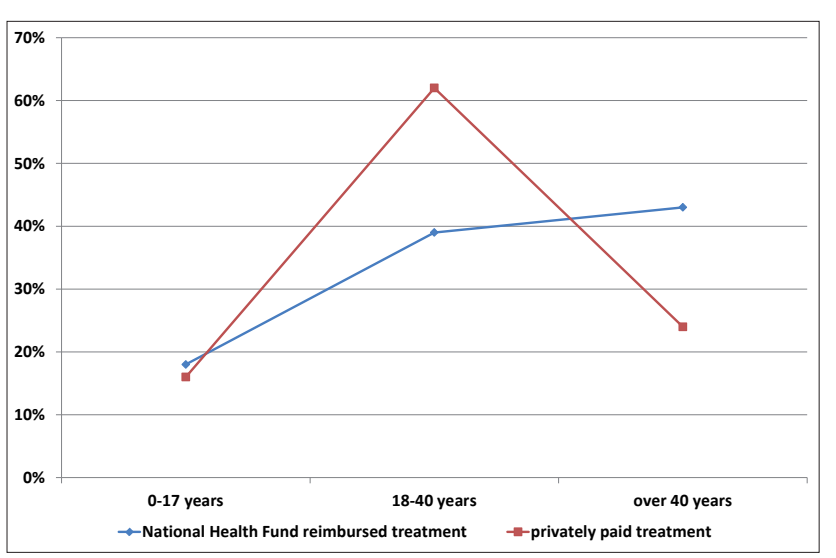

Figure 4. Number of reimbursed and non-reimbursed procedures according to patients' age

\section{DISCUSSION}

Dental care in Poland is based both on the public system (reimbursement by the National Health Fund) and on the private funding. Our study showed that slightly over $60 \%$ of the patients were treated under a contract with the National Health Fund; this result was close to the one obtained in a similar analysis conducted in the eastern part of the Wielkopolska Province [4]. The analysis by Suchecka and Laskowska indicated that $30.9 \%$ of all the studied households received dental care that was not financed by the National Health Fund [8]. Among the patients treated under a contract with the National Health Fund in the Wielkopolska Province, 54.13\% were women and $45.87 \%$ - men, while the percentages of adult patients and those at the developmental age were $79.82 \%$ and $20.18 \%$, respectively [4]. The regularities found in the cited research and in our study are similar. Other authors' research shows that the frequency of using dental care is distinctly greater among women than among men [1,2]; the same is obtained in the case of an interest in aesthetic treatment to improve the aesthetics of one's teeth [5]. In our study, women made use of the treatment reimbursed by the National Health Fund slightly more often than men did.

The present study shows an increase in the number of reimbursed procedures along with an increase in the patients' age. The relationship between the kind of financing and patients' age was earlier indicated by Leśniewski and Bocianowski [4]. In the case of non-reimbursed procedures, the number of procedures in our study material increased in patients below 40 years of age, to decrease considerably in patients over 40. This may indicate a discrepancy between the reimbursed types of treatment and the actual needs of patients.

In a majority of patients, both in the group that paid for treatment from their own funds and in the group that had their treatment reimbursed, therapeutic procedures were highly significantly more frequent than prophylactic ones, and conservative treatment prevailed in all age groups. As daily practice and clinical experience of the authors show, it is a rule that conservative treatment procedures are predominant at general dental care offices, in this case, at a primary dental care office.
Prophylactic procedures constituted $28.95 \%$ of all procedures provided to patients aged $0-17$ years, $14.1 \%$ - in the group aged $18-40$ years, and $8.8 \%$ in patients over 40 years. Undoubtedly, the fact that the National Health Fund reimburses teeth varnishing in patients not older than 18 and sealing in those not older than 7 years of age, influenced the prevalence in our study material of prophylactic procedures in patients who received reimbursed treatment in the youngest age group.

In our study, in the group of patients receiving endodontic treatment, as much as $67.74 \%$ of all the patients paid for their treatment with their funds. This is related to the fact that endodontic treatment of lateral teeth in adult patients is not reimbursed. Similarly, the cost of the treatment with permanent prosthetic replacements is not refunded [7]. Undoubtedly, the lack of reimbursement for endodontic treatment will result in a deterioration of teeth condition and in an increase of edentulous persons in the Polish population. The program "Oral Cavity Health Monitoring" for 2009 showed that the percentage of edentulous Poles at the age $65-74$ years was as high as $43.9 \%$ of the population, and only $49.6 \%$ of the population at this age preserved their masticatory function [11].

The negative tendencies are confirmed by an analysis of procedures performed in the particular age groups; the analysis shows that the number of tooth extractions increased significantly with age, from $14.95 \%$ in patients below 40 years of age to $70.09 \%$ in patients over 40 . At the same time, a decrease in endodontic treatment occurred in the study material: form $59.14 \%$ (below 40 years) to $36.56 \%$ (over 40 years).

An increasing awareness of patients and their satisfaction with services provided by private dental offices, as well as an improvement in dental services availability $[3,6,9,10]$, combined with a limited range of services reimbursed by the National Health Fund, induce patients to use private treatment more and more frequently. In our study, prophylactic procedures, ozonisation, dental whitening, and endodontic treatment - which is extremely important in patients younger than 40 , were performed in the group of patients covering the treatment in full. This indicates that the patient's greater financial resources enable using a wider range of services conforming to the current results of medical science.

\section{CONCLUSIONS}

1. Procedures reimbursed by the National Health Fund constituted slightly over $60 \%$ of services provided to patients at a dental office.

2. Both among the procedures reimbursed by the National Health Fund and non-reimbursed procedures, therapeutic procedures highly significantly prevailed over the prophylactic ones; in all age groups conservative treatment was predominant.

3. An increase in the number of extractions in patients over 40 years of age was found.

4. The number of the procedures reimbursed by the National Health Fund, compared to the not-reimbursed ones, increased with the age of patients. 


\section{REFERENCES}

1. Kałużna A.: Poziom świadomości w zakresie zdrowia jamy ustnej poradni stomatologicznej w Koninie. Mag. Stomatol., 5, 72, 2003.

2. Kopacz S., Kopacz M.: Usługi stomatologiczne z perspektywy pacjenta. Ouintesence Tech. Dent., 12, 254, 2004.

3. Lempe B., Woźniak Z., Żurowski M.: Pacjenci gabinetów prywatnych o reformie i usługach gwarantowanych w opiece stomatologicznej. Stom. Współcz., 9, 47, 2002.

4. Leśniewski G., Bocianowski J.: Analiza wpływu sposobu finansowania usług na rodzaj wykonywanych zabiegów. Mag. Stomatol., 9, 133, 2006.

5. Nowakowska-Socha J.: Stomatologiczne leczenie estetyczne w obecnych warunkach socjoekonomicznych oraz jego wpływ na higienę i samoocenę u leczonych pacjentów na podstawie badań ankietowych i klinicznych. Annales Academiae Medicae Stetinensis Roczniki Pomorskiej Akademii Medycznej w Szczecinie, 53,100, 2007.
6. Pawka B., Wdowiak L., Lis J. et al.: Zadowolenie pacjentów Z usług stomatologicznych. Zdr. Publ., 114, 184, 2004.

7. Pytko-Polończyk J., Loster B.W.: Lecznicze potrzeby stomatologiczne pacjentów zgłaszających się do Uniwersyteckiej Kliniki Stomatologicznej w Krakowie w roku 2008. Implantoprotetyka, 10, 48, 2009.

8. Suchecka J., Laskowska I.: Finansowanie świadczeń medycznych ze środków prywatnych w okresie transformacji system ochrony zdrowia w Polsce. Rozprawy Ubezpieczeniowe nr 5(2/2008). www.rzu.gov.pl

9. Wroński K.: Świadomość pacjenta o wymogu jakości świadczonych usług stomatologicznych. Stom. Wspót., 18, 12, 2011.

10. Wroński K., Bocian R., Depta A.: Opinia pacjentów o celowości badania ich satysfakcji z usług stomatologicznych. Stom. Współ., 17, 10, 2010.

11. Wyniki badań epidemiologicznych prowadzonych $\mathrm{w}$ ramach programu „Monitoring Zdrowia Jamy Ustnej” w 2008 i 2009 roku. www2.mz.gov.pl/wwwfiles/ma_struktura/docs/wyniki_ moni_25012011.pdf 